\title{
Expression of micro-RNAs and genes related to angiogenesis in CCRCC and associations with tumor characteristics
}

\author{
Rita de Cássia Oliveira', Renato Fidelis Ivanovic ${ }^{1}$, Katia Ramos Moreira Leite', Nayara Izabel Viana', \\ Ruan César Aparecido Pimenta ${ }^{1}$, José Pontes Junior ${ }^{1,2}$, Vanessa Ribeiro Guimarães ${ }^{1}$, Denis Reis Morais ${ }^{1}$, \\ Daniel Kanda Abe ${ }^{1}$, Adriano João Nesrallah², Miguel Srougi', William Nahas ${ }^{2}$ and Sabrina Thalita Reis ${ }^{1 *}$
}

\begin{abstract}
Background: Clear cell renal cell carcinoma (ccRCC) is the third most common urological cancer in adults. Our aim is to evaluate genes and miRNAs expression profiles involved with angiogenesis and tumor characteristics in ccRCC.

Methods: The expression levels of miRNAs miR-99a, 99b, 100; 199a; 106a; 106b; 29a; 29b; 29c; 126; 200a, 200b and their respective target genes: mTOR, HIF1-a, VHL, PDGF, VEGF, VEGFR1 and VEGFR2 were analyzed using qRT-PCR in tumor tissue samples from 56 patients with ccRCC. Five samples of benign renal tissue were utilized as control. The expression levels of miRNAs and genes were related to tumor size, Fuhrman nuclear grade and microvascular invasion.

Results: miR99a was overexpressed in most samples and its target gene mTOR was underexpressed, this also occurs for miRNAs 106a, 106b, and their target gene VHL. An increase in miR-200b was correlated with high-risk tumors ( $p=0$. 01) while miR-126 overexpression was associated with Fuhrman's low grade ( $p=0.03$ ).
\end{abstract}

Conclusions: Our results show that in cCRCC there are changes in miRNAs expression affecting gene expression that could be important in determining the aggressiveness of this lethal neoplasia.

Keywords: Angiogenesis, Genes, microRNAs, Renal cell carcinoma clear cell type

\section{Background}

Clear cell renal cell carcinoma (ccRCC) is the third most common urological cancer after prostate and bladder cancer and represents approximately $3 \%$ of cancers in adults as well as $85 \%$ of primary malignant kidney tumors [1]. Early detection and correct follow-up of the patients may influence the prognosis of the disease. Therefore, to improve our understanding of ccRCC pathogenesis, is necessary to identify new biomarkers enabling prediction of early metastasis after nephrectomy, and develop new targeted therapies [2].

MicroRNAs (miRNAs) are a class of small noncoding RNA with approximately 22 nucleotides and has critical roles in a many biological processes through translational

\footnotetext{
* Correspondence: sasareis@gmail.com

${ }^{1}$ Laboratory of Medical Investigation (LIM55), Urology Department, University of Sao Paulo Medical School, Av. Dr. Arnaldo 455, $2^{\circ}$ floor, room 2145, Sao Paulo 01246-903, Brazil

Full list of author information is available at the end of the article
}

repression or degradation of target messenger RNAs (mRNAs). Dysregulation of miRNAs has been shown to result in gene expression alteration and contributes to invasion and metastasis of many human tumors [3]. Prior studies indicated that miRNAs are also involved in other processes like tumor angiogenesis [4, 5]. Particularly, many urologic tumors have altered levels of numerous miRNAs [6]. Thus, changed expression of miRNAs may be useful for diagnosis, prediction of prognosis and treatment selection in patients with certain urologic cancers [7, 8]. Remarkably, targeted disruption of angiogenesisrelated miRNAs may be a potential target treatment for RCC and other cancers [9].

ccRCC is characteristically highly vascularized and related to a germinative mutation of the von HippleLindau (VHL) gene. Under adequate oxygen conditions, the VHL protein controls the expression of HIF-1 $\alpha$ leading to its ubiquitination and degradation by the proteasome. In the absence of the VHL protein, due to gene 
mutation and or deletion, even during normal oxygen conditions HIF1- $\alpha$ will bind to the constitutively expressed HIF1, thus forming a heterodimer (HIF-1) activating transcription of genes related to angiogenesis and cell survival as VEGF, EGFR, PDGF, TGF- $\alpha$, erythropoietin [10] ERK and mTOR. The discovery of the VHL-HIF1 pathway was responsible for the developing of target drugs represented by monoclonal antibodies and molecules responsible for tyrosine kinase inhibition action [11].

Some microRNAs have been called angiomirs because they regulate the angiogenesis process [12]. miR-126 [13]; miR-100, [14], miR-200 [15] and miR-26a [16] are some examples of this group of miRNAs.

Few studies have evaluated the presence of angiomirs in tumor development in urology, specially in ccRCC $[17,18]$. Our aim is to evaluate genes and miRNAs expression profiles involved with angiogenesis and tumor characteristics in ccRCC.

\section{Clinical significance}

The association between these biomarkers and ccRCC may contribute to the development of alternative tools that can facilitate the early detection and prognosis of this disease.

\section{Methods}

\section{Patients}

The study comprised the analysis of specimens from 56 patients diagnosed with ccRCC who were surgically treated by radical or partial nephrectomy at Hospital das Clinicas of University of Sao Paulo Medical School between January/2008 and March/2012 (Table 1). Final pathological status, tumor size, Fuhrman's nuclear grade and micro vascular invasion were retrospectively reviewed. Patients were grouped according to a prognosis classification described by Dall'Oglio et al. into high, intermediate and low risk tumors [19]. The control group was composed of normal kidney tissues from patients with ureteropelvic junction obstruction.

The expression levels of the following miRNAs (miR99a, 99b, 100; 199th; 106a; 106b; 29a; 29b; 126; 200b) and their target genes (mTOR, HIF1- $\alpha$, VHL, PDGF- $\beta$, VEGFA, VEGFR2) were correlated to ccRCC prognostic factors. Follow-up was 12 months at least and all samples had their confidentiality guaranteed.

Subjects provided written informed consent to participate the study and allowed their biological samples to be genetically analyzed. Approval for the study was given by the Institutional Board of Ethics (CAPPesq - Comissão de Ética para Análise de Projetos de Pesquisa) under the number 352891.

\section{Storage of samples}

The surgical specimens were collected immediately after surgery. Tumor fragments with almost $1 \mathrm{~cm}^{2}$ were placed
Table 1 Pathological and Clinical characteristics of the patients

\begin{tabular}{ll}
\hline Age (years) & \\
\hline Average & 63.2 \\
Median & 51 \\
Gender & $37(66.0 \%)$ \\
Male & $19(33.9 \%)$ \\
Female & $16(28.6 \%)$ \\
Parcial Nephrectomy & $40(71.4 \%)$ \\
Radical Nephrectomy & \\
Fuhrman's Grade & $32(57.2 \%)$ \\
1-2 & $24(42.8 \%)$ \\
3-4 & \\
Microvascular Invasion & $44(78.6 \%)$ \\
Absent & $12(21.4 \%)$ \\
Present & \\
Pathological Stage (T) & $26(46.4 \%)$ \\
pT1-T2 & $30(53.6 \%)$ \\
PT3-T4 & \\
Pathological Stage (N) & \\
N0 & $54(96.4 \%)$ \\
N1 & $02(3.6 \%)$ \\
Mathological Stage (M) & \\
M1 & $48(85.7 \%)$ \\
\hline
\end{tabular}

into RNA later (Sigma-Aldrich, St. Louis, MO, USA) and stored at $-80{ }^{\circ} \mathrm{C}$. The samples were used for the analysis of miRNAs and target genes expression. We analyzed miR-99a, 99b, 100; 199th; 106a; 106b; 29a; 29b; 126 and 200b and their target genes mTOR, HIF1- $\alpha$, VHL, PDGF- $\beta$, VEGFA and VEGFR2.

\section{miRNA isolation of RNA and CDNA synthesis}

We used the mirVana kit (Ambion, Austin, TX) for RNA and miRNA extraction, and cDNA was obtained using the TaqMan miRNA Reverse Transcription kit (Applied Biosystems, Foster City, CA) for miRNA and the HighCapacity cDNA Reverse Transcription kit for RNA according to the manufacturer's recommendations. A quantity of $10 \mathrm{ng}$ miRNA was subjected to miRNAs of interest sequence-specific primer stem-loop reverse transcription. The PCR reaction for obtaining cDNA from miRNA was performed using Veriti equipment (Applied Biosystem, Foster City, CA) according to the following parameters: $30 \mathrm{~min}$ at $16{ }^{\circ} \mathrm{C}, 30 \mathrm{~min}$ at $42{ }^{\circ} \mathrm{C}$, and $5 \mathrm{~min}$ at $85{ }^{\circ} \mathrm{C}$. The same equipment was used to obtain cDNA from RNA with the following parameters: $10 \mathrm{~min}$ at $25{ }^{\circ} \mathrm{C}, 120 \mathrm{~min}$ at $37^{\circ} \mathrm{C}$, and $5 \mathrm{~min}$ at $85^{\circ} \mathrm{C}$. 


\section{cDNA synthesis}

Complementary DNA (cDNA) was obtained using miRNA TaqMan'miRNA Reverse Transcription Kit (Applied Biosystems, Foster City, CA) with the following quantities: A quantity of $200 \mathrm{ng} / \mathrm{l}$ miRNA was diluted in $20 \mu \mathrm{L}$ of water. $3 \mathrm{uL}$ of this volume was subjected to reverse transcription, which was added $7 \mu \mathrm{L}$ mix containing the kit reagents: $0,15 \mu \mathrm{l}$ DNTP mix $0,5 \mu \mathrm{l}$ the enzyme reverse transcriptase, the enzyme $1,5 \mu$ buffer of $0,19 \mu \mathrm{l}$ RNAse inhibitor, 3,66 $\mu \mathrm{l}$ nuclease of free water and $1 \mu \mathrm{l}$ of primer with stem-loop sequence to specific miRNA totaling $10 \mu \mathrm{l}$ cDNA. The PCR reaction for obtaining cDNA from miRNA was performed using Veriti equipment (Applied Biosystem, Foster City, CA) according to the following parameters: $30 \mathrm{~min}$ at $16{ }^{\circ} \mathrm{C}$, $30 \mathrm{~min}$ at $42{ }^{\circ} \mathrm{C}$, and $5 \mathrm{~min}$ at $85^{\circ} \mathrm{C}$.

The same equipment was used to obtain cDNA from RNA with the following parameters: $10 \mathrm{~min}$ at $25^{\circ} \mathrm{C}$, $120 \mathrm{~min}$ at $37{ }^{\circ} \mathrm{C}$, and $5 \mathrm{~min}$ at $85{ }^{\circ} \mathrm{C}$. The RNA cDNA synthesis was performed using the High-Capacity cDNA Reverse Transcription ${ }^{\circ}$ kit (Applied Biosystems) using reverse transcriptase and random primers Multiscribe ${ }^{\mathrm{Tm}}$. The total RNA was diluted in nuclease-free $\mathrm{H} 2 \mathrm{O}$ to a final volume of $20 \mu \mathrm{l}$ and concentration of $500 \mu \mathrm{L} / \mathrm{ng}$. In this volume were added $4 \mu \mathrm{l}$ of random oligonucleotides (10X), $1,6 \mu \mathrm{l}$ dNTP mix (25X), $4 \mu \mathrm{l}$ of enzyme buffer (10X) $2 \mu \mathrm{l}$ of the enzyme reverse transcriptase and $8,4 \mu \mathrm{l}$ nuclease-free water. The solution was then subjected to temperature cycling $\left(25{ }^{\circ} \mathrm{C}\right.$ for $10 \mathrm{~min}, 37{ }^{\circ} \mathrm{C}$ for $120 \mathrm{~min}$ and $85{ }^{\circ} \mathrm{C}$ for $5 \mathrm{~min}$ ) in Veriti ${ }^{\circ}$ thermocycler (Applied Biosystems). At the end of both cDNA reactions were stored at $-20{ }^{\circ} \mathrm{C}$ until use.

\section{Analysis of miRNA and RNA expression}

The miRNA and RNA expression levels were analyzed by qRT-PCR using an ABI 7500 Fast Real-Time PCR System (Applied Biosystems). The target sequences were amplified in a $10 \mu \mathrm{l}$ reaction containing $5 \mu \mathrm{l}$ TaqMan Universal PCR Master Mix, $0.5 \mu \mathrm{l}$ TaqMan Gene Expression Assays, $1 \mu \mathrm{l} \mathrm{cDNA}$, and $3.5 \mu \mathrm{l}$ DNase-free water. The PCR cycling conditions were $2 \mathrm{~min}$ at $50^{\circ} \mathrm{C}, 10 \mathrm{~min}$ at $95{ }^{\circ} \mathrm{C}$, and 40 cycles of $15 \mathrm{~s}$ at $95^{\circ} \mathrm{C}$ and $1 \mathrm{~min}$ at $60^{\circ}$ C. All reactions were performed in duplicate, and TaqMan B2M and RNU 43 were utilized as the endogenous controls for gene and microRNA expression, respectively.

We used the CT method to calculate the relative expression of the microRNA and target genes using the formula $\mathrm{CT}=(\mathrm{CT}$ target gene, ccRCC sample CT endogenous control, ccRCC sample) - (CT target gene, Control sample - CT endogenous control, Control sample). The fold change in gene expression was calculated as $2^{-\mathrm{CT}}$.

\section{Statistical analysis}

Statistical analyzes were performed using SPSS 19.0 software for Windows (SPSS Inc., Chicago, USA). T student test or Mann-Whitney tests were used to compare the expression of miRNAs miR-99a, 99b, 100; 199th; 106a; 106b; 29a; 29b; 29c; 126; 200a, 200b with their target genes and ccRCC size, clinical stage and Fuhrman's grade nuclear. A $p$ value $\leq 0.05$ was considered statistically significant for all calculations.

\section{Results}

ccRCC angiogenesis gene and miRNA expression profile

The genes with the highest overexpression were VEGFA (84\%) and PDGF (86\%) while mTOR (88\%) and VHL (86\%) presented the lowest expressions (Table 2). Genes with moderate expression included: VEGFR1 (59\%), VGFR2 (55\%) and HIF1- $\alpha$ (57\%) (Fig. 1). The miRNAs which were overexpressed were: miR-99a (80.0\%), miR99b (94.0\%), miR-200b (95\%), miR-106a (100\%) and miR-106b (97\%). miRNAs 126 and 100 appeared underexpressed in $81.0 \%$ and $67.0 \%$ of patients, respectively. miRNAs 199a, 29a and 29b presented a very heterogeneous expression (Fig. 2).

\section{cCRCC angiogenesis gene and miRNA expression profile and prognostic factor}

We studied the correlation between the ccRCC angiogenesis miRNAs and gene expressions with the prognostic factors. Considering gene expression, although not statistically significant we observed an increased of HIF1- $\alpha$ gene expression in patients with micro vascular invasion $(p=0.08)$. An increase in miR-200b correlated with high-risk tumors $(p=0.01)$ while miR-126 overexpression was associated with Fuhrman's low grade ( $p=$ 0.03 ) (Tables 3 and 4).

Univariate analysis revealed that pathological stage, tumor size, Fuhrman's nuclear grade and micro vascular invasion were significantly different in patients with high-risk tumors $(p=0.000 ; p=0.000 ; p=0.000 ; p=$ 0.000 , respectively). To determine statistically significant clinical variables related to prognosis classification we used multivariate analysis to identify the importance of the isolated factors. Results showed that tumor size (0.475, 95\% CI 0.436-0.777, $p=0.000)$, High Fuhrman's nuclear grade $(0.492,95 \%$ CI $0.479-0.780, p=0.000)$, micro vascular invasion present $(0.332$, 95\% CI $0.378-$ $0.730, p=0.000$ ) and miR-200b greater than 13.06 (vs 13.06 or more) $(0.159,95 \%$ CI $0.076-0.331, p=0.003)$ were independently related to the high-risk tumors.

\section{cCRCC miRNA expression profile and target genes}

A possible regulatory effect could be speculated for miR99a overexpression $(86 \%)$ and a mTOR underexpression (71.6\%), A similar result was observed between VEGFA 
Table 2 Gene expression and prognostic factors of cCRCC

\begin{tabular}{|c|c|c|c|c|c|c|c|}
\hline & mTOR & VEGFR1 & VEGFR2 & VEGFA & HIF1A & PDGF & $\mathrm{VHL}$ \\
\hline Low $(n=18)$ & $0.63(1.32)$ & $1.96(2.10)$ & $3.17(6.12)$ & $11.87(16.14)$ & $1.56(2.27)$ & $5.91(11.18)$ & $0.29(1.04)$ \\
\hline Intermediate $(n=29)$ & $1.32(5.43)$ & $1.84(4.85)$ & $1.11(1.38)$ & $7.10(4.47)$ & $1.05(1.29)$ & $4.27(9.39)$ & $18.28(87.65)$ \\
\hline High $n=9$ & $0.55(0.63)$ & $4.48(6.10)$ & $1.51(2.26)$ & $4.20(4.58)$ & $3.12(5.58)$ & $7.05(9.53)$ & $5.18(6.73)$ \\
\hline$p$ & $0.82^{b}$ & $0.37^{\mathrm{b}}$ & $0.89^{b}$ & $0.18^{\mathrm{b}}$ & $0.43^{b}$ & $0.76^{\mathrm{b}}$ & $0.67^{b}$ \\
\hline Size $\geq 7 \mathrm{~cm}(n=30)$ & $0.52(1.11)$ & $1.74(2.06)$ & $2.41(5.14)$ & $10.33(13,53)$ & $1.27(1.97)$ & $6.62(12.76)$ & $0.39(1.20)$ \\
\hline Size $<7 \mathrm{~cm}(n=26)$ & $1.54(5.84)$ & $2.69(5.81)$ & $1.31(1.72)$ & $6.32(4.45)$ & $1.74(3.10)$ & $3.56(5.17)$ & $18.84(85.70)$ \\
\hline$p$ & $0.97^{\mathrm{a}}$ & $0.59^{\mathrm{a}}$ & $0.87^{\mathrm{a}}$ & $0.17^{\mathrm{a}}$ & $0.50^{\mathrm{a}}$ & $0.97^{\mathrm{a}}$ & $0.12^{\mathrm{a}}$ \\
\hline MVI absent $(n=44)$ & $0.45(0.95)$ & $2.03(4.11)$ & $2.08(4.27)$ & $9.77(11.28)$ & $1.10(1.63)$ & $5.24(10.57)$ & $12.54(72.60)$ \\
\hline MVI present $(n=12)$ & $3.39(9.18)$ & $2.75(4.76)$ & $1.10(1.71)$ & $3.61(3.57)$ & $2.91(4.36)$ & $4.89(7.41)$ & $3.66(5.73)$ \\
\hline$p$ & $0.25^{\mathrm{a}}$ & $0.61^{\mathrm{a}}$ & $0.46^{\mathrm{a}}$ & $0.57^{\mathrm{a}}$ & $0.08^{\mathrm{a}}$ & $0.91^{\mathrm{a}}$ & $0.68^{a}$ \\
\hline Fuhrman's Grade I e II ( $n=32)$ & $1.43(5.32)$ & $1.57(1.79)$ & $2.43(4.97)$ & $9.86(13.09)$ & $1.54(2.11)$ & $4.39(9.21)$ & $0.19(0.84)$ \\
\hline Fuhrman's Grade III e IV $(n=24)$ & $0.40(0.52)$ & $3.00(6.10)$ & $1.19(1.68)$ & $6.57(4.81)$ & $1.45(3.06)$ & $6.17(10.97)$ & $20.65(89.28)$ \\
\hline$p$ & $0.81^{\mathrm{a}}$ & $0.45^{\mathrm{a}}$ & $0.56^{\mathrm{a}}$ & $0.26^{\mathrm{a}}$ & $0.89^{\mathrm{a}}$ & $0.51^{\mathrm{a}}$ & $0.13^{\mathrm{a}}$ \\
\hline Metastasis Absent $(n=48)$ & $0.46(0.93)$ & $1.81(2.86)$ & $1.96(4.14)$ & $8.53(11.20)$ & $1.54(2.76)$ & $5.59(10.78)$ & $1.18(3.44)$ \\
\hline Metastasis Present $(n=8)$ & $3.64(9.71)$ & $4.03(8.24)$ & $1.41(2.10)$ & $7.98(4.54)$ & $1.27(1.20)$ & $3.05(3.04)$ & 54.33(151.70) \\
\hline $\mathrm{p}$ & $0.82^{\mathrm{a}}$ & $0.49^{\mathrm{a}}$ & $0.71^{\mathrm{a}}$ & $0.89^{\mathrm{a}}$ & $0.77^{\mathrm{a}}$ & $0.49^{\mathrm{a}}$ & $0.79^{\mathrm{a}}$ \\
\hline pT1-2 $(n=26)$ & $0.51(1.16)$ & $1.33(1.74)$ & $2.47(5.31)$ & $10.12(14.05)$ & $1.47(2.13)$ & $7.07(13.16)$ & $0.20(0.86)$ \\
\hline pT3-4 $(n=30)$ & $1.48(5.62)$ & $3.03(5.63)$ & $1.33(1.72)$ & $6.83(4.67)$ & $1.53(2.95)$ & $3.34(4.95)$ & $19.00(85.67)$ \\
\hline$p$ & $0.38^{\mathrm{a}}$ & $0.51^{\mathrm{a}}$ & $0.97^{\mathrm{a}}$ & $0.26^{\mathrm{a}}$ & $0.80^{\mathrm{a}}$ & $0.16^{\mathrm{a}}$ & $0.18^{\mathrm{a}}$ \\
\hline
\end{tabular}

${ }^{\mathrm{a}}$ Mann-Whitney test ${ }^{\mathrm{b}}$ Kruskall-Wallis Test

(77\% overexpressed) and miR-126 (78\% under expressed) and miR-106a (100\%) and 106b (97\%), both overexpressed; with VHL gene underexpression (86\%) (Figs. 1 and 2).

\section{Discussion}

ccRCC is considered the sixth leading cause of cancer deaths in Western countries. The incidence of this neoplasia is steadily increasing in the last years, each year; around 200,000 patients are diagnose with this disease resulting in approximately 100,000 deaths $[20,21]$. The angiogenesis, process of development of capillaries from preexisting blood vessels, is essential for the growth of malignant tumors [22]. The VEGFA pathway plays an important role in regulating the process of angiogenesis, and von Hippel Lindau (VHL) gene loss or the hypoxia may explain the increased expression of this gene. In both situations, the HIF1- $\alpha$ gene moves to the cell nucleus, promoting VEGFA and PDGFa transcription [10, 23], As a result many drugs targeting angiogenesis have been developed and are currently being used to treat metastatic disease [24-26].

The importance of angiogenesis regulatory genes is not restricted to targeted therapy. Djordjevic et al. demonstrated that overexpression VEGFA gene was

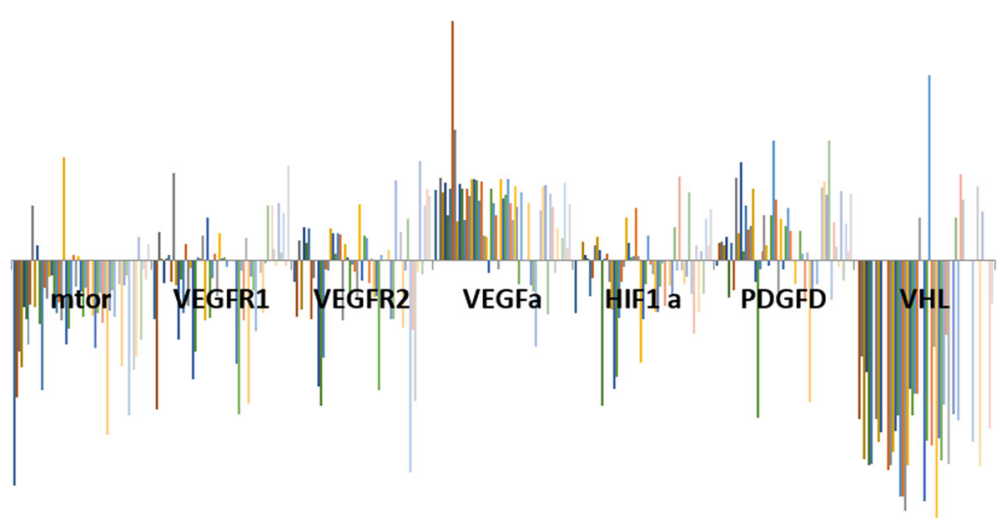

Fig. 1 Graphical representation of the expression levels of genes related to angiogenesis in CcRCC tissue compared with control 


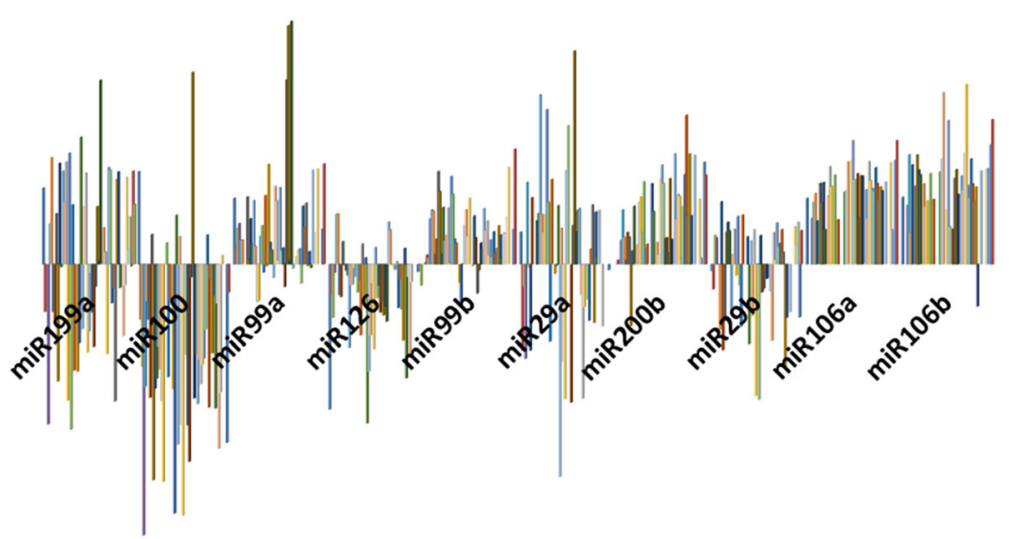

Fig. 2 Graphical representation of the expression levels of miRNAs related to angiogenesis in cCRCC tissue compared with control

associated with high Fuhrman's grade [27]. Also, Burgesser et al. correlated the expression of VEGFA, HIF1a, CD34 and Ki67 with most important prognostic factors in RCC in 83 patients. VEGFA expression was related to shorter survival rate after nephrectomy.

Our study is consistent with previous findings since we have found VEGFA overexpression that could be related to VHL under expression. It may be possible that in our cohort the mechanism involved in tumor development was VHL gene loss. However, we did not see HIF1- $\alpha$ overexpression in our cohort. On the contrary,
HIF1- $\alpha$ was under expressed in $57 \%$ of our cases. However, when microvascular invasion was present, HIF1- $\alpha$ had higher expression compared to patients without microvascular invasion (no statistical significance).

Maybe, HIF1- $\alpha$ could be a marker of micro vascular invasion. Berghoffet. al. observed HIF1- $\alpha$ levels in brain metastasis samples from RCC, melanoma, breast, lung and colorectal cancer by immunohistochemistry. Increased HIF1- $\alpha$ levels were found in brain metastases from the RCC patients, and these had major effects on angiogenesis when compared to other tumors [28].

Table 3 miRNA expression and prognostic factors of ccRCC

\begin{tabular}{|c|c|c|c|c|c|c|c|}
\hline & miR-199a & miR-100 & miR-99a & miR-99b & miR-126 & miR-29a & miR-29b \\
\hline Low $(n=18)$ & $60.12(104.18)$ & $0.51(1.34)$ & 17.89(34.38) & $22.01(37.5)$ & $2.10(4.1)$ & $19.25(28.23)$ & $3.94(7.35)$ \\
\hline Intermediate $(n=29)$ & 59.99(159.22) & $5.62(25.37)$ & $22.18(49.15)$ & $13.07(31.1)$ & $0.96(2.9)$ & $10.90(28.49)$ & $2.72(2.89)$ \\
\hline High $n=9$ & $48.64(85.19)$ & $0.77(1.75)$ & $44.44(75.01)$ & 65.13(159.) & $0.37(0.3)$ & $7.05(9.72)$ & $5.30(2.91)$ \\
\hline$P$ & $0.65^{\mathrm{b}}$ & $0.63^{b}$ & $0.50^{b}$ & $0.17^{\mathrm{b}}$ & $0.29^{\mathrm{b}}$ & $0.57^{\mathrm{b}}$ & $0.47^{\mathrm{b}}$ \\
\hline Size $\geq 7 \mathrm{~cm}(n=30)$ & 61.13(91.26) & $5.69(26.31)$ & 19.77(39.93) & $22.79(42.3)$ & $1.57(3.6)$ & $13.80(24.88)$ & $3.48(6.21)$ \\
\hline Size $<7 \mathrm{~cm}(n=26)$ & $55.80(166.90)$ & $0.90(2.77)$ & $27.68(56.40)$ & $23.59(84.3)$ & $1.02(2.1)$ & $12.62(28.97)$ & $3.29(2.90)$ \\
\hline$P$ & $0.88^{\mathrm{a}}$ & $0.36^{\mathrm{a}}$ & $0.57^{\mathrm{a}}$ & $0.96^{\mathrm{a}}$ & $0.49^{\mathrm{a}}$ & $0.88^{\mathrm{a}}$ & $0.12^{\mathrm{a}}$ \\
\hline MVI absent $(n=44)$ & $63.00(145.83)$ & $3.90(20.87)$ & $15.77(34.2)$ & $17.73(35.1)$ & $1.55(3.2)$ & $15.24(29.69)$ & $3.19(5.13)$ \\
\hline MVI present $(n=12)$ & $43.28(73.27)$ & $0.88(1.80)$ & $51.97(76.99)$ & 43.48(127.) & $0.36(0.3)$ & $5.37(7.45)$ & $4.30(3.50)$ \\
\hline$P$ & $0.65^{\mathrm{a}}$ & $0.63^{\mathrm{a}}$ & $0.05^{\mathrm{a}}$ & $0.72^{\mathrm{a}}$ & $0,43^{\mathrm{a}}$ & $0.33^{\mathrm{a}}$ & $0.54^{\mathrm{a}}$ \\
\hline Fuhrman's Grade I e II ( $n=32)$ & 39.95(87.23) & $0.49(1.32)$ & $23.61(45.13)$ & $17.40(31.4)$ & $1.92(3.7)$ & $19.08(34.41)$ & $3.63(6.04)$ \\
\hline Fuhrman's Grade III e IV $(n=24)$ & $79.35(169.23)$ & $6.35(26.88)$ & $23.28(52.73)$ & $29.41(88.9)$ & $0.55(1.2)$ & $5.70(7.80)$ & $3.11(3.06)$ \\
\hline$p$ & $0.28^{\mathrm{a}}$ & $0.33^{\mathrm{a}}$ & $0.98^{\mathrm{a}}$ & $0.51^{\mathrm{a}}$ & $0.03^{\mathrm{a}}$ & $0.10^{\mathrm{a}}$ & $0,71^{\mathrm{a}}$ \\
\hline pT1-2 $(n=26)$ & $50.88(82.18)$ & $6.36(27.40)$ & $22.79(42.04)$ & $23.35(43.8)$ & $1.19(2.7)$ & $14.85(25.19)$ & $3.86(6.32)$ \\
\hline pT3-4 $(n=30)$ & $65.37(166.50)$ & $0.69(2.59)$ & 24.12(53.93) & $23.01(81.1)$ & $1.41(3.1)$ & $11.84(28.52)$ & $2.96(3.03)$ \\
\hline$P$ & $0.69^{\mathrm{a}}$ & $0.28^{\mathrm{a}}$ & $0.92^{\mathrm{a}}$ & $0.98^{\mathrm{a}}$ & $0.78^{\mathrm{a}}$ & $0.71^{\mathrm{a}}$ & $0.51^{\mathrm{a}}$ \\
\hline Metastasis Absent $(n=48)$ & $49.76(84.62)$ & $3.46(19.85)$ & 19.01(39.85) & $25.78(69.88)$ & $1.17(2.54)$ & $12.23(26.81)$ & $3.61(418.33)$ \\
\hline Metastasis Present $(n=8)$ & 107.88(286.69) & $1.89(4.94)$ & 48.92(81.75) & $6.41(6.35)$ & $2.20(5.18)$ & $18.95(28.74)$ & $2.24(3.24)$ \\
\hline$p$ & $0.25^{\mathrm{a}}$ & $0.83^{\mathrm{a}}$ & $0.12^{\mathrm{a}}$ & $0.47^{\mathrm{a}}$ & $0.39^{a}$ & $0.57^{\mathrm{a}}$ & $0.46^{\mathrm{a}}$ \\
\hline
\end{tabular}

${ }^{\mathrm{a}}$ Mann-Whitney test ${ }^{\mathrm{b}}$ Anova ${ }^{\mathrm{b}}$ Kruskall-Wallis Test

significant $p$-value are highlighted in bold 
Table 4 Continuation of the miRNA expression and prognostic factors of cCRCC

\begin{tabular}{|c|c|c|c|}
\hline & miR-200b & miR-106a & miR-106b \\
\hline Low $(n=18)$ & 43.39(89.17) & 65.14(65.16) & 159.44(171.94) \\
\hline Intermediate $(n=29)$ & $58.51(98.63)$ & $110.15(141.57)$ & $90.68(85.67)$ \\
\hline High $n=9$ & $563.01(1128.21)$ & 202.94(270.20) & $123.81(100.46)$ \\
\hline$P$ & $0.01^{\mathrm{b}}$ & $0.23^{b}$ & $0.31^{b}$ \\
\hline Size $\geq 7 \mathrm{~cm}(n=30)$ & $57.91(97.01)$ & $79.23(68.51)$ & $125.34(140.61)$ \\
\hline Size <7 cm $(n=26)$ & $162.81(545.59)$ & 139.51(196.72) & $102.81(92.03)$ \\
\hline P & $0.36^{\mathrm{a}}$ & 0.766 & $0.58^{\mathrm{a}}$ \\
\hline MVI absent $(n=44)$ & $55.97(95.09)$ & $93.38(127.07)$ & $119.47(126.44)$ \\
\hline MVI present $(n=12)$ & 355.35(899.73) & $173.31(213.58)$ & $94.63(90.02)$ \\
\hline$p$ & $0.53^{\mathrm{a}}$ & $0.17^{\mathrm{a}}$ & $0.17^{\mathrm{a}}$ \\
\hline Fuhrman's Grade I e II ( $n=32)$ & $56.44(99.57)$ & 103.91(158.18) & $135.37(152.50)$ \\
\hline Fuhrman's Grade III e IV $(n=24)$ & $169.48(557.25)$ & 113.84(143.83) & $101.01(92.55)$ \\
\hline P & $0.33^{\mathrm{a}}$ & $0.83^{\mathrm{a}}$ & $0.40^{\mathrm{a}}$ \\
\hline pT1-2 (n= 26) & 48.99(94.76) & $67.86(60.49)$ & 115.03(103.12) \\
\hline pT3-4 $(n=30)$ & $161.87(521.68)$ & 143.33(187.99) & $115.59(136.84)$ \\
\hline$P$ & $0.33^{\mathrm{a}}$ & $0.11^{\mathrm{a}}$ & $0.98^{\mathrm{a}}$ \\
\hline Metastasis Absent $(n=48)$ & 119.99(0.47) & $117.25(5.12)$ & 109.83(122.37) \\
\hline Metastasis Present $(n=8)$ & $50.56(114.07)$ & $54.21(43.87)$ & 149.38(113.15) \\
\hline$p$ & $0.66^{\mathrm{a}}$ & $0.38^{\mathrm{a}}$ & $0.50^{\mathrm{a}}$ \\
\hline
\end{tabular}

${ }^{\mathrm{a}}$ Mann-Whitney test ${ }^{\mathrm{b}}$ Anova ${ }^{\mathrm{b}}$ Kruskall-Wallis Test

significant $p$-value are highlighted in bold

In the present study, a moderate PDGF gene expression (63\%) could be seen. Wang et al. through microarray tests on 174 patients studied the role of PDGF-B and its receptor (PDGFR- $\beta$ ) in RCC progression. As PDGF-B expression increased among the samples a significant reduction in risk of death was found. In addition, PDGF-B induction in xenograft mice models could inhibit tumor growth and reduce cell proliferation [29].

In our study, mTOR was under expressed in $88 \%$ of patients, but it was increased in patients with adverse prognostic factors such as micro vascular invasion and metastatic disease, although not statistically significant. Similarly, Haddad et al. proved that mTOR, expression was inversely correlated to bad prognostic factors like high grade tumors and presence of necrosis in patients with ccRCC treated by nephrectomy [30].

Many papers reported changes in gene expression as prognostic markers. However they cannot be applied yet into clinical practice due to inaccuracy in comparison to known classical factors [31]. Thus, the investigation of new molecular markers cannot be considered finished.

At this point miRNA expression profile in ccRCC is not limited to determine new prognostic factors but also to explain molecular mechanisms related to its development and progression.

As previously mentioned, MicroRNAs are small noncoding RNAs that regulate the expression of target genes by translation repression or transcriptional regulation, so playing a role in many biological pathways $[2,7]$. miRNAs have been classified as tumor suppressor or oncogenes [2]. Actually, miRNAs are estimated to regulate $30 \%$ of all gene transcripts, it is highly possible that their aberrant expression will contribute to ccRCC formation by altering the balance between oncogenes and tumor suppressor genes. When oncogenic miRNAs are overexpress in tumors, tumor suppressor genes are downregulated $[6,32]$.

Genes previously studied may be controlled by one or more microRNAs. miR-126 was under expressed in 78\% of cases and has VEGFA gene as target that was overexpressed in $77 \%$ of the cases. Similar results were described by Khella et al. in a study where the opposite expression of miR-126 and VEGFA was identified [33]. In addition, in this paper, we provide important evidence in supporting of miR-126 functioning as a tumor suppressor in ccRCC, because miR-126 underexpression was associated with higher histological grade. miR-126 is considered a highly conserved miRNA with increased expression in vascularized tissues [34]. This miRNA has been reported to be associated with tumorigenesis of many types of cancer [35]. Wong et al. [36] showed that lower level of miR-126 represents tumor recurrence and poor survival in the HCC patients who received liver transplant surgery confirming our data in ccRCC. 
VEGFA receptors can be controlled by miR-200b [37]. In our study, miR-200b was overexpressed while VEGFA receptors were moderately under expressed. While VEGFR1 and 2 genes were not correlated with any of the prognostic factors, miR-200b had a positive correlation with high risk neoplasms according to the pathological triad [19]. This is the first study to report miR-200b as a prognostic factor in ccRCC. Also, in prostate cancer our group demonstrated that overexpression of miR-200b correlated with localized tumors while its low expression was associated with locally advanced tumors (pT3), Gleason $>8$ and shorter free biochemical recurrence survival [38].

Another inverse correlation, which suggests a regulatory mechanism is the VHL gene underexpression (86\%) and its regulatory miRNAs overexpression: miR-106a (100\%) and miR-106b (97\%). The posttranscriptional inhibition performed by miR-106a and miR-106b may represent another mechanism other than gene mutation or even increase the effects of the mutation nullifying the intact allele. This is supported by experiments, which have silenced the VHL gene, leading to an increased in HIF1 and VEGFA expression [39]. These miRNAs have been described as prognostic factors in RCC but we were unable to demonstrate any association [40].

Finally, we demonstrated that miR-99a was overexpressed in $80 \%$ of the samples whereas mTOR was decreased in $88 \%$. Cui et al. studied the effects of miR-99a over mTOR gene by miR-99a transfection in cell lines and RCC xenograft models. The miR-99a acts by inhibiting mTOR gene expression in both cell lines and in experimental models. It was confirmed that the high expression of miR-99a interfered with the G-1 phase of the cell cycle and delayed cell proliferation, decreasing tumor progression in vivo [41]. miR-99a did not correlate with clinical or pathological characteristics in our study, but the antagonist relationship with mTOR gene corroborates with the study by Cui et al. [41].

Some limitations of our study should be mentioned. This is a retrospective study and the number of patients is low in the control group and would be interesting to validate the results with a larger number of controls and cases enrolled prospectively. In a prospective study, it becomes easier to add behavioral characteristics of patients, like smoking and obesity that all may potentially interfere with analysis of recurrence, which was not possible in our work because we did not have this information. Moreover, the validation of these results in serum sample and functional studies in RCC cell line can improve the quality of our study and the clinical applicability of the results.

\section{Conclusion}

In conclusion, we can postulate the role of miR-200b and miR-126 in the prognosis of this neoplasia. Our results support that in ccRCC there is an unbalance in the expression of genes and miRNAs related to process as angiogenesis, cell proliferation and survival. These finding besides helping us to understand the molecular mechanism of ccRCC gives us a reason to further investigate miR-126 and miR-200b as a potential biomarker and therapeutic target for this neoplasia.

\section{Abbreviations}

cCRCC: Clear cell renal cell carcinoma; cDNA: Complementary DNA; miRNAs: MicroRNAs; mRNAs: Messenger RNAs; VHL: Von Hipple-Lindau

\section{Acknowledgements}

CNPq 440564/2014-1.

\section{Funding}

This study was supported by CNPq (Conselho Nacional de desenvolvimento científico e tecnológico) under protocol number 440564/2014-1.

\section{Availability of data and materials}

Data sets generated and / or analyzed during the present study are available at the Faculty of Medicine of the University of São Paulo - FMUSP-SP, LIM55. Sabrina Thalita Reis, sasareis@gmail.com.

\section{Authors' contributions}

Study concept and design: STR, KRML, RCO. Acquisition of data: DKA, AJN, MS, WN. Analysis and interpretation of data: NIV, RCAP, RFI, VRG, DRM. Drafting of the manuscript: STR, RCO, RFI. Funding acquisition: NIV, RCAP. Critical revision of the manuscript for important intellectual content: STR, KRML, MS. All authors read and approved the final manuscript.

\section{Ethics approval and consent to participate}

All samples used in this study were coded, guaranteeing their confidentiality. Subjects provided written informed consent to participate the study and allowed their biological samples to be genetically analyzed. Approval for the study was given by the Institutional Board of Ethics (CAPPesq - Comissão de Ética para Análise de Projetos de Pesquisa) under the number 352.891.

\section{Consent for publication}

Not applicable.

\section{Competing interests}

The authors declare that they have no competing interests.

\section{Publisher's Note}

Springer Nature remains neutral with regard to jurisdictional claims in published maps and institutional affiliations.

\section{Author details \\ 'Laboratory of Medical Investigation (LIM55), Urology Department, University of Sao Paulo Medical School, Av. Dr. Arnaldo 455, $2^{\circ}$ floor, room 2145, Sao Paulo 01246-903, Brazil. Uro-Oncology Group, Urology Department, University of Sao Paulo Medical School and Institute of Cancer Estate of Sao Paulo (ICESP), Sao Paulo, Brazil.}

Received: 31 March 2017 Accepted: 22 November 2017

Published online: 04 December 2017

\section{References}

1. Bukowski RM. Prognostic factors for survival in metastatic renal cell carcinoma: update 2008. Cancer. 2009;115(10 Suppl):2273-81.

2. Schaefer A, Stephan C, Busch J, Yousef GM, Jung K. Diagnostic, prognostic and therapeutic implications of microRNAs in urologic tumors. Nature reviews Urology. 2010;7(5):286-97.

3. Adams BD, Kasinski AL, Slack FJ. Aberrant regulation and function of microRNAs in cancer. Current biology : CB. 2014;24(16):R762-76.

4. Suarez $Y$, Sessa WC. MicroRNAs as novel regulators of angiogenesis. Circ Res. 2009;104(4):442-54. 
5. Bridge G, Monteiro R, Henderson S, Emuss V, Lagos D, Georgopoulou D, Patient $\mathrm{R}$, Boshoff $\mathrm{C}$. The microRNA-30 family targets DLL4 to modulate endothelial cell behavior during angiogenesis. Blood. 2012;120(25):5063-72.

6. Catto JW, Alcaraz A, Bjartell AS, De Vere White R, Evans CP, Fussel S, Hamdy FC, Kallioniemi O, Mengual L, Schlomm T, et al. MicroRNA in prostate, bladder, and kidney cancer: a systematic review. Eur Urol. 2011;59(5):671-81.

7. Schaefer A, Jung M, Kristiansen G, Lein M, Schrader M, Miller K, Stephan C, Jung K. MicroRNAs and cancer: current state and future perspectives in urologic oncology. Urol Oncol. 2010;28(1):4-13.

8. Ru Y, Dancik GM, Theodorescu D. Biomarkers for prognosis and treatment selection in advanced bladder cancer patients. Curr Opin Urol. 2011;21(5): 420-7.

9. Fendler A, Stephan C, Yousef GM, Jung K. MicroRNAs as regulators of signal transduction in urological tumors. Clin Chem. 2011;57(7):954-68.

10. Longo R, D'Andrea MR, Sarmiento R, Salerno F, Gasparini G. Integrated therapy of kidney cancer. Annals of oncology: official journal of the European Society for Medical Oncology / ESMO. 2007;6(18 Suppl):vi141-8.

11. Smaldone MC, Maranchie JK. Clinical implications of hypoxia inducible factor in renal cell carcinoma. Urol Oncol. 2009;27(3):238-45.

12. Zhang C. MicroRNAs in vascular biology and vascular disease. J Cardiovasc Transl Res. 2010;3(3):235-40.

13. van Solingen $C$, Seghers $L$, Bijkerk R, Duijs JM, Roeten MK, van OeverenRietdijk AM, Baelde HJ, Monge M, Vos JB, de Boer HC, et al. Antagomirmediated silencing of endothelial cell specific microRNA-126 impairs ischemia-induced angiogenesis. J Cell Mol Med. 2009;13(8A):1577-85.

14. Grundmann S, Hans FP, Kinniry S, Heinke J, Helbing T, Bluhm F, Sluijter JP, Hoefer I, Pasterkamp G, Bode C, et al. MicroRNA-100 regulates neovascularization by suppression of mammalian target of rapamycin in endothelial and vascular smooth muscle cells. Circulation. 2011;123(9):999-1009.

15. Roy S, Sen CK: miRNA in wound inflammation and angiogenesis. Microcirculation (New York, NY: 1994) 2012, 19(3):224-232.

16. Li Y, Fan L, Liu S, Liu W, Zhang H, Zhou T, Wu D, Yang P, Shen L, Chen J, et al. The promotion of bone regeneration through positive regulation of angiogenic-osteogenic coupling using microRNA-26a. Biomaterials. 2013; 34(21):5048-58.

17. Zaravinos A, Radojicic J, Lambrou Gl, Volanis D, Delakas D, Stathopoulos EN Spandidos DA. Expression of miRNAs involved in angiogenesis, tumor cell proliferation, tumor suppressor inhibition, epithelial-mesenchymal transition and activation of metastasis in bladder cancer. J Urol. 2012;188(2):615-23.

18. Yuan HX, Zhang JP, Kong WT, Liu YJ, Lin ZM, Wang WP, Guo JM. Elevated microRNA-185 is associated with high vascular endothelial growth factor receptor 2 expression levels and high microvessel density in clear cell renal cell carcinoma. Tumour Biol. 2014;35(12):12757-63.

19. Dall'Oglio MF, Antunes AA, Sarkis AS, Crippa A, Leite KR, Lucon AM, Srougi M. Microvascular tumour invasion in renal cell carcinoma: the most important prognostic factor. BJU Int. 2007;100(3):552-5.

20. Miyamoto H, Miller JS, Fajardo DA, Lee TK, Netto GJ, Epstein Jl. Non-invasive papillary urothelial neoplasms: the 2004 WHO/ISUP classification system. Pathol Int. 2010:60(1):1-8

21. Montironi R, Santinelli A, Pomante R, Mazzucchelli R, Colanzi P, Filho AL, Scarpelli M. Morphometric index of adult renal cell carcinoma. Comparison with the Fuhrman grading system. Virchows Archiv : an international journal of pathology. 2000;437(1):82-9.

22. Eklund L, Bry M, Alitalo K. Mouse models for studying angiogenesis and lymphangiogenesis in cancer. Mol Oncol. 2013;7(2):259-82.

23. Ebbinghaus SW, Gordon MS. Renal cell carcinoma: rationale and development of therapeutic inhibitors of angiogenesis. Hematol Oncol Clin North Am. 2004;18(5):1143-59. ix-x

24. Choueiri TK, Bukowski RM, Rini BI. The current role of angiogenesis inhibitors in the treatment of renal cell carcinoma. Semin Oncol. 2006;33(5): 596-606.

25. Ljungberg BJ, Jacobsen J, Rudolfsson SH, Lindh G, Grankvist K, Rasmuson T. Different vascular endothelial growth factor (VEGF), VEGF-receptor 1 and -2 mRNA expression profiles between clear cell and papillary renal cell carcinoma. BJU Int. 2006;98(3):661-7.

26. Posadas EM, Limvorasak S, Sharma S, Figlin RA. Targeting angiogenesis in renal cell carcinoma. Expert Opin Pharmacother. 2013;14(16):2221-36.

27. Djordjevic G, Mozetic V, Mozetic DV, Licul V, llijas KM, Mustac E, Oguic R, Fuckar Z, Jonjic N. Prognostic significance of vascular endothelial growth factor expression in clear cell renal cell carcinoma. Pathol Res Pract. 2007; 203(2):99-106.
28. Berghoff AS, Ithan-Mutlu A, Dinhof C, Magerle M, Hackl M, Widhalm G, Hainfellner JA, Dieckmann K, Pichler J, Hutterer M, et al. Differential role of angiogenesis and tumour cell proliferation in brain metastases according to primary tumour type: analysis of 639 cases. Neuropathol Appl Neurobiol. 2015;41(2):e41-55

29. Wang W, Qi L, Tan M, Zhang Z, Du J, Wei X, Yao X. Effect of platelet-derived growth factor-B on renal cell carcinoma growth and progression. Urologic oncology. 2015;33(4):168.e117-27.

30. Haddad AQ, Kapur P, Singla N, Raman JD, Then MT, Nuhn P, Buchner A, Bastian P, Seitz C, Shariat SF, et al. Validation of mammalian target of rapamycin biomarker panel in patients with clear cell renal cell carcinoma. Cancer. 2015;121(1):43-50.

31. Bui MH, Zisman A, Pantuck AJ, Han KR, Wieder J, Belldegrun AS. Prognostic factors and molecular markers for renal cell carcinoma. Expert Rev Anticancer Ther. 2001;1(4):565-75.

32. Chow TF, Youssef YM, Lianidou E, Romaschin AD, Honey RJ, Stewart R, Pace $K T$, Yousef GM. Differential expression profiling of microRNAs and their potential involvement in renal cell carcinoma pathogenesis. Clin Biochem. 2010;43(1-2):150-8.

33. Khella HW, White NM, Faragalla H, Gabril M, Boazak M, Dorian D, Khalil B, Antonios $\mathrm{H}$, Bao TT, Pasic MD, et al. Exploring the role of miRNAs in renal cell carcinoma progression and metastasis through bioinformatic and experimental analyses. Tumour Biol. 2012;33(1):131-40.

34. Nikolic I, Plate KH, Schmidt MH. EGFL7 meets miRNA-126: an angiogenesis alliance. J Angiogenes Res. 2010;2(1):9.

35. Harris TA, Yamakuchi M, Ferlito M, Mendell JT, Lowenstein CJ. MicroRNA-126 regulates endothelial expression of vascular cell adhesion molecule 1. Proc Natl Acad Sci U S A. 2008;105(5):1516-21.

36. Wong QW, Lung RW, Law PT, Lai PB, Chan KY, To KF, Wong N. MicroRNA223 is commonly repressed in hepatocellular carcinoma and potentiates expression of Stathmin1. Gastroenterology. 2008;135(1):257-69.

37. Silva-Santos RM, Costa-Pinheiro P, Luis A, Antunes L, Lobo F, Oliveira J, Henrique R, Jeronimo C. MicroRNA profile: a promising ancillary tool for accurate renal cell tumour diagnosis. Br J Cancer. 2013;109(10):2646-53.

38. Katz B, Reis ST, Viana NI, Morais DR, Moura CM, Dip N, Silva IA, Iscaife A, Srougi M, Leite KR. Comprehensive study of gene and microRNA expression related to epithelial-mesenchymal transition in prostate cancer. PLoS One. 2014;9(11):e113700.

39. Zhang T, Niu X, Liao L, Cho EA, Yang H. The contributions of HIF-target genes to tumor growth in RCC. PLoS One. 2013;8(11):e80544.

40. Slaby O, Jancovicova J, Lakomy R, Svoboda M, Poprach A, Fabian P, Kren L, Michalek J, Vyzula R. Expression of miRNA-106b in conventional renal cell carcinoma is a potential marker for prediction of early metastasis after nephrectomy. Journal of experimental \& clinical cancer research : CR. 2010; 29:90.

41. Cui L, Zhou H, Zhao H, Zhou Y, Xu R, Xu X, Zheng L, Xue Z, Xia W, Zhang B, et al. MicroRNA-99a induces G1-phase cell cycle arrest and suppresses tumorigenicity in renal cell carcinoma. BMC Cancer. 2012;12:546.

\section{Submit your next manuscript to BioMed Central and we will help you at every step:}

- We accept pre-submission inquiries

- Our selector tool helps you to find the most relevant journal

- We provide round the clock customer support

- Convenient online submission

- Thorough peer review

- Inclusion in PubMed and all major indexing services

- Maximum visibility for your research

Submit your manuscript at www.biomedcentral.com/submit
) Biomed Central 